\title{
Demographic and clinical characterization of human visceral leishmaniasis in the State of Pernambuco, Brazil between 2006 and 2015
}

\author{
Jaqueline Maria Dos Santos Sousa[1], Walter Massa Ramalho ${ }^{[2]}$ \\ and Marcia Almeida de Melo ${ }^{[3]}$
}

\begin{abstract}
[1]. Programa de Pós-Graduação Stricto Sensu em Ciência Animal Tropical, Universidade Federal Rural de Pernambuco, Recife, PE, Brasil.
[2]. Programa de Pós-Graduação Stricto Sensu em Medicina Tropical, Universidade de Brasília, Brasília, DF, Brasil.

[3]. Programa de Pós-Graduação Stricto Sensu em Medicina Veterinária, Universidade Federal de Campina Grande, Patos, PB, Brasil.
\end{abstract}

\begin{abstract}
Introduction: Human visceral leishmaniasis (HVL) primarily occurs in regions that present socioeconomic, health, and environmental vulnerability. In Pernambuco, Brazil, this neglected zoonosis has expanded in magnitude as well as geographically, and efforts to manage HVL have been insufficient to contain its spread. The objective of this study was to describe the epidemiological profile of human illness due to HVL during 2006 to 2015 in Pernambuco State. Methods: This study was conducted using secondary data collected from the Health Information System. Results: During the study period, Pernambuco accounted for $2.4 \%$ of HVL cases in Brazil, with $49.6 \%$ of these concentrated in the macroregions of São Francisco Valley and Araripe. The percentage of municipalities that reported cases at the beginning of the study period increased from $21.1 \%(\mathrm{n}=39)$ to $43.8 \%(n=81)$ by the end of the period. Cases were found predominantly among males, brown-skinned individuals, children aged 1-4 years, and individuals with incomplete $1^{\text {st }}$ to $4^{\text {th }}$ grade education. Coinfection with HIV was present in $5.6 \%$ of cases. Incidence was 9.7 cases per 100,000 inhabitants, and lethality was $12.3 \%$. Conclusions: HVL has shown worrying expansion and evolution, in addition to high lethality, in Pernambuco. The only study of its kind in the past decade, it was evident from this study that despite efforts to contain this disease, HVL in Pernambuco exhibits patterns similar to those described in previous studies. Based on our results, we suggest reassessing the current prevention and control measures in the state.
\end{abstract}

Keywords: Zoonosis. Epidemiology. Communicable diseases. Public health surveillance.

\section{INTRODUCTION}

Visceral leishmaniasis (VL) is a chronic zoonosis caused by an intracellular protozoan of the genus Leishmania. Disease transmission through a phlebotomine vector ${ }^{1}$ involves complex interactions between the vector, parasite, and vertebrate host in different ecotypes ${ }^{2}$.

The main clinical aspects of VL in humans are hepatosplenomegaly; irregular, long-term fever; anemia with leukopenia; lymphadenopathy; edema; weight loss; and cachexia. These symptoms may progress to death ${ }^{3}$.

According to Montalvo $4,90 \%$ of HVL cases occur in economically disadvantaged countries in which a large proportion of the population is vulnerable (India, Bangladesh, Nepal, Sudan, and Brazil). Montalvo affirmed that many failures have caused a global increase in HVL cases during recent years

Corresponding author: MSc. Sp. Jaqueline Maria Dos Santos Sousa. e-mail: jaquemedvet@hotmail.com

Received 20 February 2018

Accepted 7 August 2018 in endemic areas, which are related to the increased incidence of immunosuppressed patients, increased therapeutic failures and antimicrobial resistance, and inadequate control of vectors and reservoirs.

As a worldwide zoonosis, autochthonous HVL cases occur on nearly all continents ${ }^{5}$, affecting nearly two million people each year according to estimates by the World Health Organization (WHO), and HVL is currently among the six endemic diseases considered global priorities ${ }^{6}$. In the absence of treatment, HVL can reach $10 \%$ lethality, thus making it an important neglected disease that is extremely serious and potentially fatal ${ }^{7}$.

Neglected diseases have a great impact on the morbidity and mortality of the world's population, resulting in millions of deaths and disability losses every year ${ }^{8}$. HVL disease and its epidemiology may vary in terms of space, time, socioeconomic conditions, environmental changes, factors directly related to increases in disease occurrence, and expansion in urban areas. HVL has been described in more than 12 Latin American countries, with $90 \%$ of cases occurring in Brazil where the disease affects nearly 3,000 people annually, mainly in the Northeast Region, according to Health Ministry estimates?. 
Currently, HVL is one of the most serious public health problems in Brazil, mainly owing to its geographical expansion, especially to nonendemic areas, as well as increased morbidity and mortality ${ }^{10}$, which are directly related to the precarious socioeconomic and health conditions of the population. Therefore, in addition to control measures that have already been implemented, it is necessary to take actions that go beyond the health field, guaranteeing resolution in the face of inequities in access to education, living conditions, food, and livelihoods, as well as providing environmental improvements such that a real impact on the occurrence of HVL is achieved ${ }^{11}$.

The State of Pernambuco, geographically located in the Brazilian Northeast Region, has approximately 9.4 million inhabitants and a territorial area of $98,076,021 \mathrm{~km}^{2}$. The state is divided into five mesoregions, 19 microregions, and 185 municipalities. In 2016, the estimated monthly nominal per capita household income was $\mathrm{R} \$ 872$, the average Human Development Index (HDI) was 0.67 , the incidence of poverty was $52.5 \%$, the Gini index was 0.5 , and the average life expectancy at birth was 73.5 years $^{12}$.

Some of the most important factors that influence the environmental aspects of disease in Pernambuco include that only $79.1 \%$ of urban households are supplied by the municipal water network, only $52.8 \%$ have sanitary sewage via sewage or rainwater collection systems, $85 \%$ are served by waste collection service (direct or indirect), and only $49.1 \%$ of households have simultaneous access to these three services ${ }^{12}$.

Between 2010 and 2013, the Northeast Region accounted for $51.4 \%$ of the HVL cases in Brazil. During this period, Pernambuco occupied the $11^{\text {th }}$ position $(2 \%)$ with respect to the number of cases ${ }^{13}$. Historically in this state, human cases are often associated with anthropogenic pressure on the environment. The disease has most frequently affected children, and the geographic distribution of cases is concentrated in the Agreste and Sertão regions ${ }^{14-16}$.

There is evidence that the measures used to stop the progression of HVL in Brazil have not resulted in a substantial reduction in the occurrence of disease ${ }^{17}$. Therefore, the objective of this study was to describe the epidemiological profile of human cases reported as HVL in the period from 2006 to 2015 in Pernambuco, to provide evidence in support of the reassessment of prevention and control measures currently used in this state.

\section{METHODS}

We conducted a descriptive, cross-sectional study using secondary data from the Notifiable Diseases Information System (SINAN) ${ }^{18}$, provided by the State Health Secretariat of Pernambuco (SES-PE). Information about HVL in the state was collected for the period 2006 to 2015 . The authors also collected data during the same period from SINAN-NET, referring to cases reported by Brazil's federal units, and the Mortality Information System (SIM) referring to deaths owing HVL. Data collection was performed from April 1 to 30, 2017.

We evaluated the mortality rates, incidence, and cases of Visceral leishmaniasis (HVL) human immunodeficiency virus (HIV) coinfection as well as the distribution parameters by age, sex, education level, and disease evolution. Data from the Brazilian Institute of Geography and Statistics (IBGE) on sanitary sewage, monthly per capita income, and HDI of the municipalities with intense or moderate HVL transmission were also collected for the period 2011 to 2015. The HDI is an indicator that uses the variables of life expectancy, income, and education to evaluate the living conditions of people in a given country, with values ranging from 0 to 1 . HDI scores are as follows: low, 0-0.499; mean, 0.500-0.799; high, 0.800-0.899; and very high, $\geq 0.900$.

According to the Health Ministry, classification of the HVL transmission level in Brazilian municipalities considers the average number of cases in the last 5 years, resulting in the following categories: no transmission (average $=0$ cases); sporadic transmission (mean $>0$ and $<2.4$ cases); moderate transmission (mean $\geq 2.4$ and $<4.4$ cases) and intense transmission (mean $\geq 4.4$ cases) ${ }^{19}$. Considering the same percentiles but using cutoff values between 2011 and 2015, Cardim $^{20}$ defined another classification (low, moderate, and high incidence), which is comparable to that obtained using the average number of cases. We used this criterion to classify the municipalities with HVL transmission between 2011 and 2015.

The data were tabulated and analyzed using descriptive statistics through calculation of the relative frequencies. The results are presented as percentages in the form of tables, graphs, and maps, using Microsoft Office Excel 2007 (Windows 7-Microsoft, Redmond-USA) and QGis 2.14 (QGIS Development Team, Essen-Germany). In addition, the coefficient of incidence per 100,000 inhabitants per year in Brazil was also calculated.

This work is in accordance with the ethical standards of the responsible institutional committee and with the Declaration of Helsinki (1964). It was done through the signing of the Free and Informed Consent Form by the participants and was approved by the Research Ethics Committee under registration number CEP 1.969.353.

\section{RESULTS}

Of the total cases per unit of the Federation between 2006 and 2015, 89.9\% were concentrated in the States of Ceará, Minas Gerais, Maranhão, Tocantins, Piauí, Bahia, Pará, Mato Grosso do Sul, São Paulo, and Pernambuco. Pernambuco accounted for $2.4 \%$ of cases during the study period, with an incidence of 9.7 cases per 100,000 inhabitants.

In the State of Pernambuco, according to data from the State Department of Health, the authors identified 907 confirmed cases of HVL between 2006 and 2015 (Figure 1). Of these, 49.6\% were concentrated in two macroregions, São Francisco Valley and Araripe. Cases were reported in the 12 health regions (RES) of Pernambuco and in 130 of the 185 municipalities. During this period, an annual average of 90.7 cases was observed. The RES with the highest incidence were VII with 65.88 cases per 100,000 inhabitants, VIII with 48.86 cases per 100,000 , and XI with 37.34 cases per 100,000.

Observation of the incidence of HVL cases per municipality from 2006 to 2015 revealed that the municipality of Carnaubeira 
da Penha of XI RES had the highest incidence during the period, with 254.63 cases per 100,000 inhabitants; this was followed by Salgueiro of VII RES with 104,19 cases per 100,000 and Tamandaré of III RES with 82.07 cases per 100,000, as shown in Figure 2.

Considering the first 2 years of the study period (2006-2015), only $21.1 \%(n=39)$ of the municipalities in Pernambuco had reported one or more cases of HVL; considering the last 2 years of the period, this percentage increased to $43.8 \%(n=81)$. According to the standard established by the Health Ministry, taking into account the last 5 years of the historical series studied (2011-2015), 37.8\% $(\mathrm{n}=70)$ of municipalities were classified as silent trasnmission, $6.5 \%(\mathrm{n}=12)$ had intense transmission, $8.6 \%(n=16)$ had moderate transmission, and $47 \%(n=87)$ had sporadic transmission of HVL (Figure 3). Using the same standard to analyze the incidence during the same period, the municipality of Santa Maria da Boa Vista showed moderate incidence whereas the municipalities of Carnaubeira da Penha, Santa Cruz, and Betânia had high incidence; the remaining

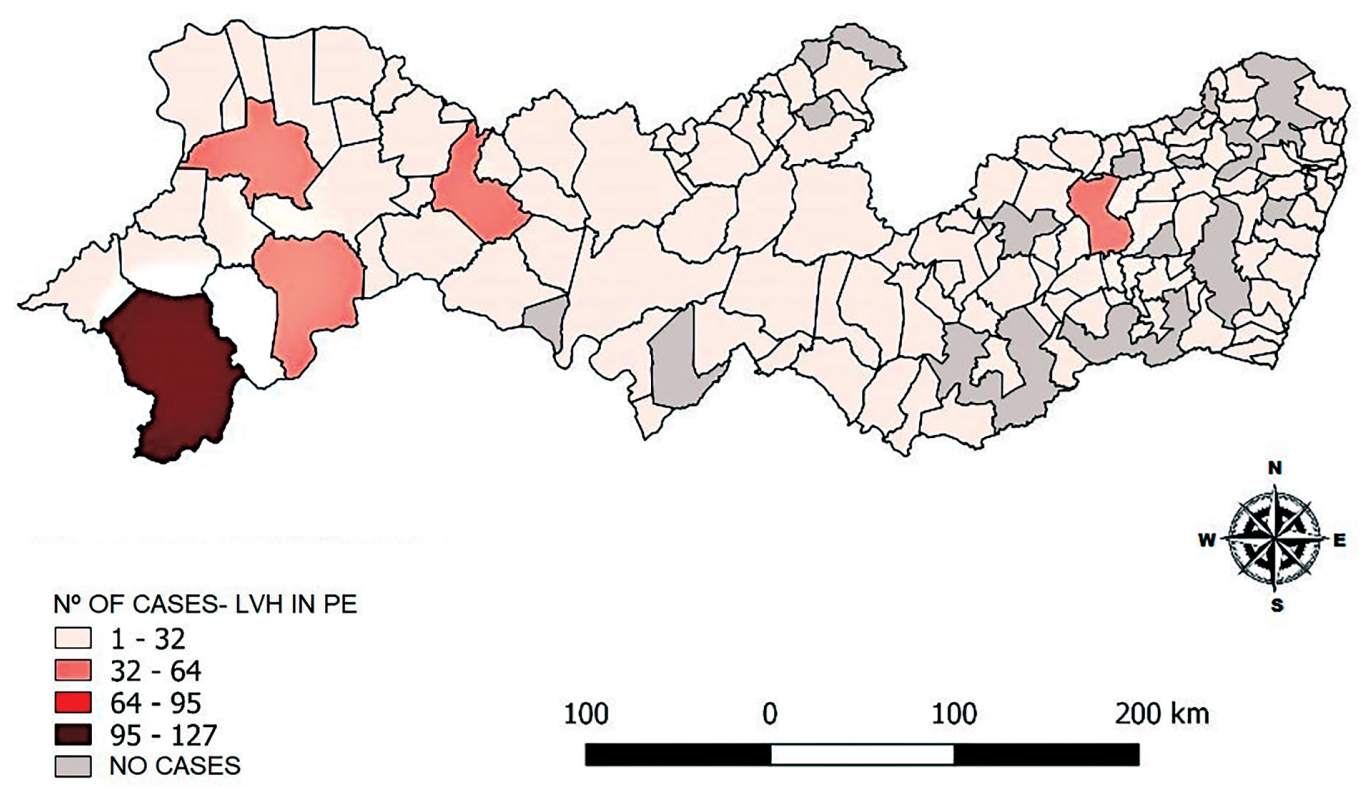

FIGURE 1: Number of cases of human visceral leishmaniasis per municipality in Pernambuco, Brazil from 2006 to 2015. Data source: State Secretariat of Health of Pernambuco - Notifiable Diseases Information System - SINAN.

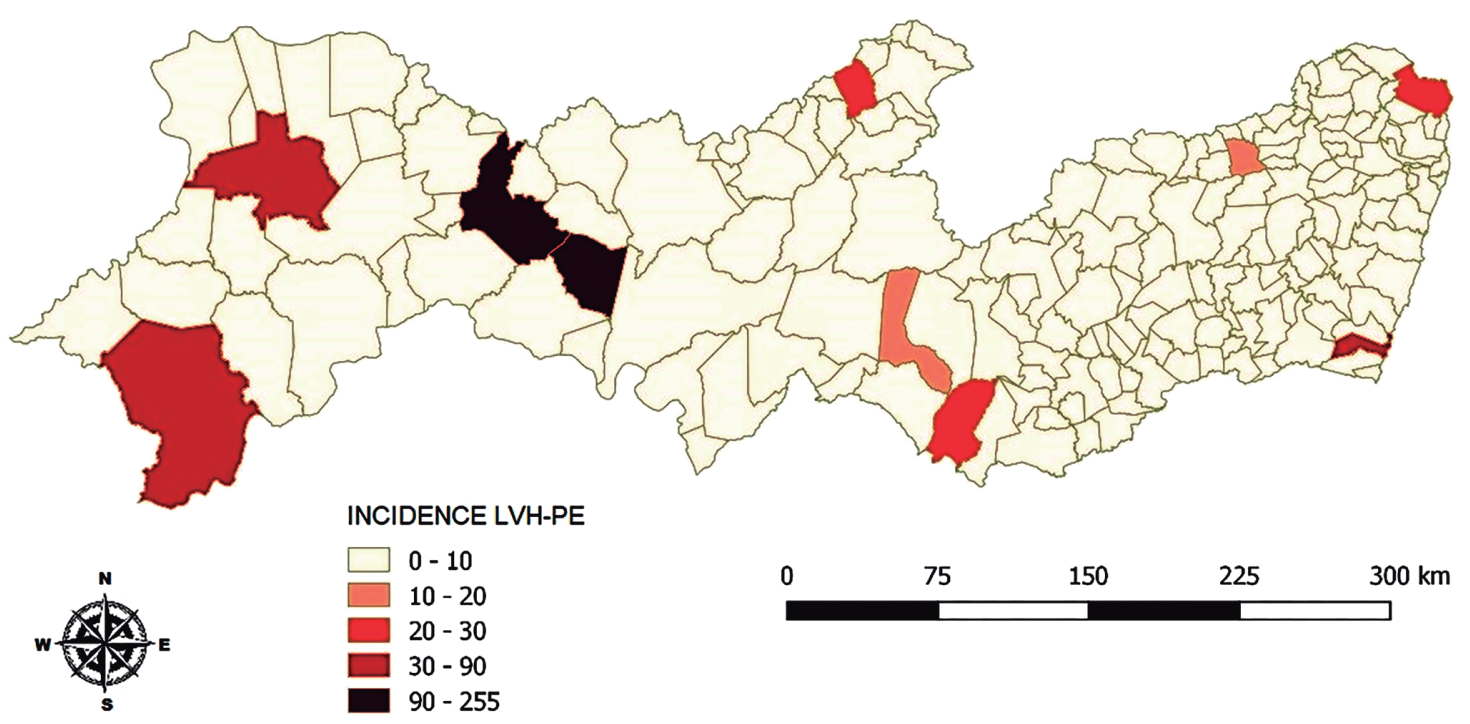

FIGURE 2: Incidence rates of human visceral leishmaniasis by municipality in Pernambuco, Brazil from 2006 to 2015. Data source: State Secretariat of Health of Pernambuco- Notifiable Diseases Information System - SINAN. 
municipalities, classified as having intense or moderate transmission, had low incidence (Table 1).

During the study period, there was irregular variation in the total number of cases, with 2015 showing the highest incidence for the period studied of 1.86 cases per 100,000 inhabitants.
Regarding the HDI, $51.7 \%(\mathrm{n}=15)$ of the 28 municipalities considered to have intense and moderate HVL transmission during the past 5 years of the historical series presented HDI scores between 0.5 and $0.6 ; 44.8 \%(\mathrm{n}=12)$ had HDI scores between 0.6 and 0.7 , and only one municipality had an HDI

TABLE 1: Number of cases per municipality and year, for municipalities classified as having intense and moderate transmission of human viral leishmaniasis in Pernambuco, Brazil from 2006 to 2015.

\begin{tabular}{|c|c|c|c|c|c|c|c|c|c|c|c|}
\hline Municipality & 2006 & 2007 & 2008 & 2009 & 2010 & 2011 & 2012 & 2013 & 2014 & 2015 & Total \\
\hline Machados & 0 & 0 & 0 & 0 & 0 & 1 & 1 & 1 & 0 & 0 & 3 \\
\hline Vicência & 0 & 0 & 0 & 0 & 0 & 2 & 0 & 0 & 0 & 0 & 3 \\
\hline Cabo de Santo Agostinho & 0 & 0 & 0 & 1 & 0 & 1 & 0 & 1 & 4 & 1 & 8 \\
\hline Jaboatão dos Guararapes & 0 & 1 & 0 & 1 & 2 & 1 & 0 & 0 & 2 & 0 & 7 \\
\hline Surubim & 1 & 2 & 4 & 0 & 0 & 1 & 0 & 2 & 1 & 0 & 11 \\
\hline Tamandaré & 0 & 3 & 3 & 3 & 4 & 0 & 0 & 0 & 4 & 0 & 17 \\
\hline Jaqueira & 0 & 0 & 0 & 0 & 0 & 1 & 0 & 0 & 4 & 0 & 5 \\
\hline Caruaru & 0 & 7 & 8 & 2 & 3 & 2 & 2 & 0 & 1 & 9 & 34 \\
\hline Altinho & 0 & 1 & 2 & 2 & 1 & 1 & 0 & 1 & 1 & 0 & 9 \\
\hline Bezerros & 0 & 0 & 0 & 0 & 0 & 0 & 0 & 0 & 0 & 3 & 3 \\
\hline Cachoeirinha & 0 & 1 & 0 & 0 & 1 & 1 & 0 & 1 & 1 & 2 & 7 \\
\hline Panelas & 0 & 4 & 0 & 0 & 0 & 0 & 1 & 2 & 0 & 0 & 7 \\
\hline Santa Cruz do Capibaribe & 0 & 1 & 1 & 0 & 0 & 0 & 4 & 0 & 0 & 1 & 7 \\
\hline Salgueiro & 0 & 3 & 4 & 6 & 4 & 6 & 6 & 7 & 16 & 7 & 59 \\
\hline Serrita & 0 & 0 & 0 & 0 & 0 & 0 & 0 & 0 & 0 & 4 & 4 \\
\hline Mirandiba & 0 & 0 & 0 & 2 & 0 & 0 & 0 & 0 & 3 & 8 & 13 \\
\hline Terra Nova & 0 & 1 & 0 & 1 & 1 & 0 & 0 & 2 & 1 & 0 & 6 \\
\hline Verdejantes & 0 & 1 & 1 & 0 & 0 & 0 & 1 & 0 & 0 & 2 & 5 \\
\hline Belém de São Francisco & 0 & 1 & 0 & 0 & 0 & 3 & 0 & 1 & 0 & 0 & 5 \\
\hline Petrolina & 0 & 17 & 12 & 5 & 14 & 13 & 16 & 11 & 22 & 17 & 127 \\
\hline Santa Maria da Boa Vista & 1 & 3 & 0 & 6 & 6 & 4 & 6 & 10 & 6 & 8 & 50 \\
\hline
\end{tabular}

Continue... 
TABLE 1: Continuation.

\begin{tabular}{|c|c|c|c|c|c|c|c|c|c|c|c|}
\hline Municipality & \multicolumn{10}{|c|}{ Years } & Total \\
\hline Cabrobó & 0 & 2 & 5 & 0 & 0 & 0 & 2 & 0 & 2 & 5 & 16 \\
\hline Lagoa Grande & 0 & 0 & 1 & 1 & 4 & 4 & 0 & 1 & 1 & 2 & 14 \\
\hline Afrânio & 0 & 0 & 2 & 3 & 0 & 0 & 0 & 0 & 5 & 1 & 11 \\
\hline Orocó & 0 & 1 & 0 & 0 & 0 & 1 & 0 & 0 & 0 & 7 & 9 \\
\hline Ouricuri & 0 & 8 & 9 & 5 & 5 & 1 & 2 & 5 & 4 & 6 & 45 \\
\hline Santa Cruz & 0 & 0 & 1 & 1 & 1 & 0 & 0 & 0 & 23 & 0 & 26 \\
\hline Araripina & 0 & 0 & 0 & 5 & 0 & 1 & 0 & 0 & 4 & 1 & 11 \\
\hline Bodocó & 0 & 0 & 0 & 0 & 1 & 0 & 0 & 0 & 1 & 4 & 6 \\
\hline Moreilândia & 0 & 0 & 0 & 0 & 0 & 0 & 1 & 1 & 1 & 1 & 4 \\
\hline Trindade & 0 & 0 & 0 & 0 & 0 & 1 & 0 & 0 & 2 & 2 & 5 \\
\hline Tabira & 0 & 0 & 0 & 0 & 0 & 1 & 0 & 0 & 2 & 4 & 7 \\
\hline Afogados da Ingazeira & 0 & 0 & 0 & 0 & 0 & 0 & 1 & 2 & 0 & 3 & 6 \\
\hline Carnaíba & 0 & 1 & 0 & 0 & 0 & 2 & 0 & 1 & 0 & 1 & 5 \\
\hline Carnaubeira da Penha & 0 & 0 & 0 & 2 & 4 & 0 & 0 & 1 & 8 & 15 & 30 \\
\hline Santa Cruz da Baixa Verde & 0 & 0 & 0 & 0 & 0 & 0 & 0 & 0 & 0 & 3 & 3 \\
\hline
\end{tabular}

Source: State Department of Health of Pernambuco - Notifiable Diseases Information System - SINAN (Produced by the authors).

above 0.7. Presently, the HDI in the State of Pernambuco is ranked $18^{\text {th }}$ among all states of the Federation ${ }^{12}$.

Analysis of the situation regarding sanitary sewage revealed that $44.8 \%(n=14)$ of municipalities had less than $50 \%$ of households with adequate sanitary sewage. We also observed that in $44.8 \%(n=14)$ of municipalities, more than $50 \%$ of the population had monthly incomes of up to half the minimum wage per person. Regarding the distribution of disease cases by sex, we verified that $63.9 \%$ of cases were among males.

As for skin color of individuals with HVL, $66 \%$ were brown, $12.3 \%$ were white, and $6.8 \%$ were black; $12 \%$ of records had missing or incomplete information regarding skin color. People of indigenous races accounted for $2.4 \%$ of all cases. Regarding age group, there were reports among individuals from all age groups. The highest incidence occurred in the age group 1-4 years, corresponding to $29.9 \%$ of cases; this was followed by the age groups 5-9 years with $16.2 \%$ of cases and $20-29$ years with $11.1 \%$ of cases. Children younger than 1 year old accounted for $1.9 \%$ of HVL cases and elderly patients (age 60 years or more) represented $5.7 \%$ of cases.

We analyzed the education level of individuals affected by HVL for the study period and found that the disease occurred more frequently among individuals that had not completed 1 st to 4 th grade education, representing $12.9 \%$ of cases. We also observed that information regarding education level was incomplete for $53.9 \%$ of the study population, and $9.6 \%$ did not have this variable fulfilled.

Of the studied cases, 5.6\% had coinfection with HIV, and $60.6 \%$ had no coinfection; information regarding coinfection was incomplete for $32.8 \%$ and not met in less than $1 \%$. In cases 


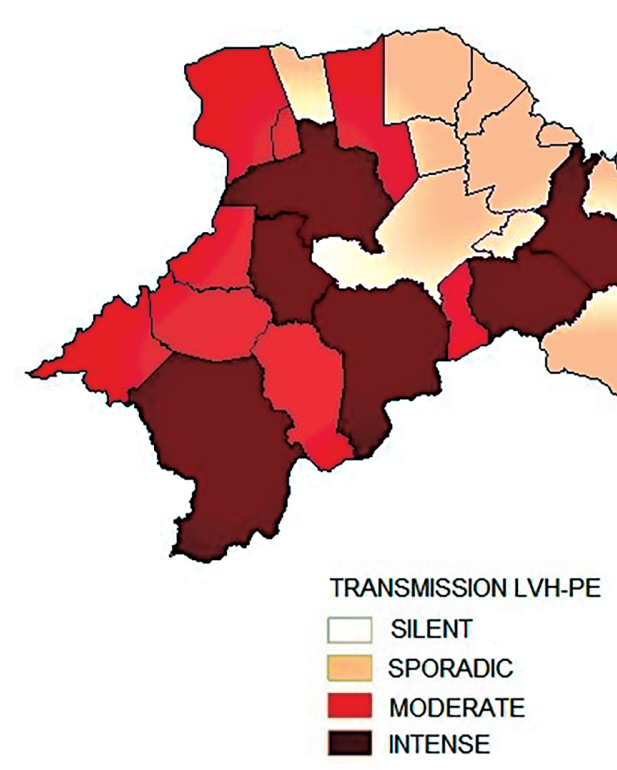

FIGURE 3: Municipalities classified according to human visceral leishmaniasis transmission in Pernambuco., Brazil from 2011 to 2015. Data source: State Secretariat of Health of Pernambuco - Notifiable Diseases Information System - SINAN.

with coinfection, $21.6 \%$ of cases were fatal; of these, $72.7 \%$ were in the age group 20-59 years.

Regarding the outcome of cases, $75.4 \%$ evolved to cure, $7.3 \%$ progressed to death; information regarding outcome was missing or incomplete in $9.6 \%$ of cases. In the period under analysis, the year with the highest lethality was 2007 with $11.8 \%$, and overall lethality was $7.3 \%$ of the total deaths, with an annual average of 6.6 deaths. According to data from SIM for the same period, 112 deaths were reported in the state, $70 \%$ more than the SINAN data, with lethality of $12.3 \%$. There was also a divergence in the data of the SINAN NET and SINAN databases, provided by the State Health Department, which showed 996 cases and 907 HVL cases, respectively.

\section{DISCUSSION}

Despite the territorial expansion of HVL, $92.9 \%$ of cases in Brazil were concentrated in the Northeast Region in 1999; this reached $47.8 \%$ of all cases in $2011^{21}$. In this study, we confirmed that this region continues to account for more than half of all HVL cases in the country, and Pernambuco is among the 10 states with the greatest number of cases. Regarding HVL occurrence in Pernambuco State, there is a higher incidence of HVL in the Agreste and Sertão regions, as previously described by several authors ${ }^{15,16,22-24}$.

It is known that the vector of HVL adapts easily to the peridomicile and varying environmental temperatures ${ }^{19}$; however, it is necessary to consider that climate change affects the transmission of various diseases by affecting the demographic process. In the early 1980s and 1990s, HVL emerged in cities of the semi-arid Brazilian Northeast Region owing to rural-urban migration of subsistence farmers whose crops had failed due to prolonged droughts ${ }^{25}$.
In the State of Pernambuco, analysis of the data of the time series of cases during the study period decade showed a total 907 cases of HVL, distributed in every state and affecting all age groups, as verified in the Integrated Plan of action for fighting neglected diseases in the State of Pernambuco ${ }^{26}$. This number is lower than those reported by Dantas-Torres \& BrandãoFilho ${ }^{15}$, with 1,203 cases between 1990 and 1997 and 1,737 cases between 1990 and 2001, respectively. This decrease in occurrence could be explained by the efficiency of the control measures adopted. However, Harvay ${ }^{27}$ and Prado $^{28}$ affirmed that the efforts and investments made thus far have not been sufficiently effective to contain the expansion of this zoonosis, and it is necessary to reassess the objectives, strategies, and methods traditionally used. Underreporting is presumed to be the probable cause of the decreased number of cases found in the present study, relative to studies conducted in previous decades in the State of Pernambuco.

According to Moreno et al..$^{29}$ and Stockdale \& Newton ${ }^{30}$, although notification is compulsory, the detection of cases is performed in a passive manner. Reliable numbers that can be used to gauge the spread of the disease are not really known, and the quality of the data is quite poor ${ }^{31}$. For the past 10 years, there have been no studies on the incidence of human cases of HVL in this state; despite the fragility of studies that are based on secondary data, this scarcity of research emphasizes the importance of the information presented here, to support current and effective decision making to reduce cases of HVL in Pernambuco State.

The high percentage of missing information in the present study made it difficult to analyze the real pattern of HVL in Pernambuco. In addition, there were varying data regarding education level, with high proportions of incomplete or missing 
information or nonresponses. These points represent a limitation of this study. According to Costa ${ }^{32}, \mathrm{Cruz}^{33}$, and Romero ${ }^{34}$, this problem creates several interpretations and questions, and is partly owing to a lack of adequate guidelines and care taken by professionals to collect complete data.

Historically, HVL has been associated with low-income profiles of the population, which makes HVL a neglected disease. According to the United Nations Development Programme (UNDP) ${ }^{35}$, the HDI is the best way to measure the development level of a nation, based on the pillars of health, education, and income, with an index of 0.8 considered a high HDI score. In this study, municipalities with HVL cases had an average HDI, associated with an absence of sanitary sewage, low family income (up to half the minimum wage per person), a brown-skinned population, and low education levels, typical factors in the epidemiology of neglected diseases. Our results showed that the social indicators analyzed for the period 2006 to 2015 present the same reality described by Dantas-Torres \& Brandão-Filho ${ }^{15}$ and Pereira et al. ${ }^{16}$ during the first decades of HVL spread in Pernambuco.

Although there are no published studies that correlate the risk of illness with ethnicity, a higher prevalence of the disease among brown-skinned populations was demonstrated in this study, corroborating the findings of Santos ${ }^{13}$ in Piauí. These results are in line with the demographic characteristics of the resident population with respect to skin color, according to the $\mathrm{IBGE}^{12}$. In the Northeast Region, the brown population predominates. Some authors have shown that the risk of HVL is associated with poor socioeconomic conditions, described in regions that also have greater proportions of people with brown skin color $^{36}$. In general, there is an indirect relationship between health and race, based on geographic, economic, and social issues that permeate this relationship and point to evidence of segregation that emerges from inequalities, mainly regarding access to diagnostic and treatment methods of disease ${ }^{37}$.

Considering the increase in the percentage of municipalities reporting cases of HVL throughout this historical series, a persistent expansion in magnitude and geography beyond the previously concentrated areas of Agreste and Sertão is evident, as cited by Dantas-Torres ${ }^{14}$, with active and intense transmission and high incidence. However, considering the annual incidence over the study period, that in Pernambuco State remained below the Brazilian average of 5.1 cases per 100, 000 inhabitants $^{38}$.

We observed a greater tendency among males to acquire HVL, corroborating the findings of Batista ${ }^{39}$, Oliveira and Pimenta ${ }^{40}$, and Cavalcante and Vale ${ }^{41}$; this can be explained by the greater exposure of these individuals to the vector ${ }^{8}$.

High prevalence of HVL among children aged 1 to 4 years was also observed by Viana et al. ${ }^{42}$ in Maranhão, and in Sergipe by Góes ${ }^{43}$, with proportions similar to those of the current study. The greater susceptibility of children can be explained by deficient immunity, greater exposure to the vector in the peridomicile, and poor nutritional status, all of which are common in endemic regions of $\mathrm{HVL}^{19}$. However, in Ceará, Cavalcante and Vale ${ }^{41}$ observed an inversion in the epidemiological profile of HVL, where the number of HVL cases in adults was higher than that observed in children, different from reports in the published literature. Those authors also corroborated the findings of this study regarding HVL/HIV coinfection in the approximate percentage of cases.

Sousa-Gomes et al. ${ }^{44}$ affirmed that both HVL and HIV have undergone recent changes in their epidemiological profiles, increasing the probability of exposure of individuals and expanding beyond the commonly affected areas and age groups. Such coinfection is a serious public health problem and requires detailed characterization, identification, and resolution of the difficulties involved in containing progression of these two diseases ${ }^{10}$.

Regarding the outcome of cases in the studied period, lethality was $7.3 \%$, similar to the findings of Santos et al. ${ }^{13}$ in Piauí and Prado et al. ${ }^{28}$ in Minas Gerais. SIM data for the same period showed lethality of $12.3 \%$, much higher than that reported by SINAN. In view of this, careful interpretation of these data is suggested because there is a clear need for improvement of the HVL databases in SINAN ${ }^{45}$. However, regardless of the database, the lethality rate is high and demonstrates the urgency of determining the main factors related to deaths due to HVL, such as more severe illness, hemorrhagic and infectious complications, comorbidities, disease spread, and failure of early diagnosis and treatment ${ }^{46}$. According to Alvarenga et al. ${ }^{47}$, there is a shortage of research on the current efficacy of the drugs of choice used to treat HVL, and greater efforts are needed to improve the care of critically ill patients to prevent death.

As a serious and potentially lethal neglected disease, there is a worrisome picture of expansion and evolution of HVL in the State of Pernambuco. Despite numerous efforts over several decades, in the past 10 years, the disease has demonstrated patterns similar to those described by several authors, reinforcing the inefficacy of current prevention and control measures.

Despite being consistent with theory, control actions that are focused on the elimination of the vector and reservoirs are difficult and ineffective in practice due to poor operation methods, lack of inputs and human resources, and few studies evaluating the real cost-effectiveness of these measures.

We suggest the reassessment of existing measures, through preparation and analysis of the implementation of new control measures integrated with other areas, such as education and social assistance. Special attention should also be paid to improvement in primary care for the detection, notification, and treatment of patients with HVL, by sensitizing professionals regarding the importance of their work in surveillance and health care. The results of the present study can help to develop a better and more current understanding of the dynamics of HVL in Pernambuco State, to support advances in the prevention and reduction of morbimortality.

\section{Conflict of interest}

The authors declare that there is no conflict of interest. 


\section{REFERENCES}

1. Cortes S, Vaz Y, Neves R, Maia C, Cardoso L, Campino L. Risk factors for canine leishmaniasis in an endemic Mediterranean region. Vet Parasitol. 2012;189(2-4): 189-96.

2. Dantas-Torres F, Solano-Gallego L, Baneth G, Ribeiro VM, Cavalcanti MP, Otranto D. Canine leishmaniasis in the Old and New Worlds: unveiled similarities and differences. Trends Parasitol. 2012;28(12):531-8.

3. Badaró R, Duarte MIS. Leishmaniose visceral. In: Veronesi R, Focaccia R, editores. Veronesi Tratado de Infectologia. $2^{\mathrm{a}}$ edition. São Paulo: Editora Atheneu; 2002. v. 2, p.1254-79.

4. Montalvo Alvarez AM, Fraga J, Monzote CL, Garcia G, Fonseca L. Diagnóstico de la leishmaniasis: de la observación microscópica del parásito a la detección del ADN. Rev Cubana Med Trop. 2012;64(2):108-31.

5. Ministério da Saúde (MS). Secretaria de Vigilância em Saúde. Boletim epidemiológico. Situação epidemiológica das zoonoses de interesse para a saúde pública. Citado: 27 ago 2017. Brasília: MS; 2010.

6. World Health Organization (WHO). Leishmaniasis. Citado: 27 ago 2017. Available at: <http://www.who.int/mediacentre/factsheets/ fs $375 / \mathrm{en} />$.

7. Desjeux P. Leishmaniasis: current situation and new perspectives. Comp Immunol Microbiol Infect Dis. 2004;27(5):305-18.

8. Utzinger J, Becker SL, Knopp S, Blum J, Neumayr AL, Keiser J, et al. Neglected tropical diseases: diagnosis, clinical management, treatment and control. Swiss Med Wkly. 2012;142(13727).

9. World Health Organization (WHO). Control of the leishmaniasis: report of a meeting of the WHO Expert Committee on the Control of Leishmaniasis. Geneva: [s.n.]; 2010. Citado: 27 ago 2017. Available at: <http://whqlibdoc.who.int/trs/WHO_TRS_949_eng.pdf $>$.

10. Martins-Melo FR, Lima MS, Alencar CH, Ramos ANJ, Heukelbach J. Epidemiological patterns of mortality due to visceral leishmaniasis and HIV/AIDS co-infection in Brazil, 2000-2011. Trans R Soc Trop Med Hyg. 2014;108(6):338-47.

11. Oliveira SS, Araújo TM. Avaliação das ações de controle da leishmaniose visceral (calazar) em uma área endêmica do Estado da Bahia, Brasil (1995-2000). Cad Saude Publica. 2003;19(6):1681-90.

12. Instituto Brasileiro de Geografia e Estatística (IBGE). Censo 2010; 2010. Citado: 2 set 2017. Disponível em: https://cidades.ibge.gov.br/ brasil/pe/pesquisa/37/30255?tipo=ranking

13. Santos GM, Barreto MTS, Monteiro MJSD, Silva RVS, Jesus RLR, Silva HJN. Aspectos epidemiológicos e clínicos da leishmaniose visceral no estado do Piauí, Brasil. Rev Cien Desenvolv. 2017;10(2):142-53.

14. Dantas-Torres F. Situação atual da epidemiologia da leishmaniose visceral em Pernambuco. Rev Saude Publica. 2006;40(3):537-41.

15. Dantas-Torres F, Brandão Filho SP. Expansão geográfica da leishmaniose visceral no Estado de Pernambuco. Rev Soc Bras Med Trop. 2006;39(4):352-56.

16. Pereira G, Machado G, Pereira R, Gadelha J, Barbosa ML. Leishmaniose visceral em Pernambuco: ados epidemiológicos. Bol Trimest Clin Doenças Infecc Parasit. 1985;5(1):53-70.

17. Costa CH, Vieira JB. Changes in the control program of visceral leishmaniasis in Brazil. Rev Soc Bras Med Trop.2001;34(2):223-28.

18. Ministério da Saúde (MS). Portaria GM/MS 104 de 2011; 2011. Citado: 30 jul 2017. Disponível em: <http://bvsms.saude.gov.br/bvs/ saudelegis/gm/2011/prt0104_25_01_2011.hml>

19. Ministério da Saúde (MS). Secretaria de Vigilância em Saúde. Departamento de Vigilância Epidemiológica. Manual de vigilância e controle da leishmaniose visceral. Brasília, DF: 2014; Citado: 3 jun 2017. Disponível em: http://bvsms.saude.gov.br/bvs/publicacoes/ manual_vigilancia_controle_leishmaniose_visceral_ledicao.pdf

20. Cardim MFM, Rodas LAC, Dibo MR, Guirado MM, Oliveira AM, Chiaravalloti Neto F. Introdução e expansão da leishmaniose visceral americana em humanos no estado de São Paulo, 1999-2011. Rev Saude Publica. 2013;47(4):691-700.

21. Ministério da Saúde (MS). Secretaria de Vigilância em Saúde. Departamento de Vigilância Epidemiológica. Casos confirmados de Leishmaniose Visceral, Brasil, Grandes Regiões e Unidades Federativas, 1990 a 2011. Brasília: MS; 2012. Citado: 29 jun 2017. Disponível em: http://portal. saude.gov.br/portal/saude/profissional/ area.cfm?id_area $=1561$.

22. Souza ZC, Brandespim DF, Agra MCR, Simões-Mattos L. Leishmaniose visceral canina e humana em Caruaru, Pernambuco, no período de 2005 a 2010. Rev Patol Trop. 2014;43(1):57-68.

23. Araujo AC, Gonçalves NNVM, Dantas-Torres F, Ferreira F, Horta MC. Visceral leishmaniasis in Petrolina State of Pernambuco, Brazil, 2007-2013. Rev Inst Med Trop Sao Paulo. 2016;58:29.

24. Soares ENL, Lima FAL, Silva ARM, Silva JCR, Coimbra AC, Almeida LP. Perfil epidemiológico da leishmanose visceral humana nas regiões de saúde do Estado de Pernambuco no período de 2004 a 2013. Rev Univ Vale Rio Verde. 2016;14(1):908-20.

25. Confalonieri UEC. Variabilidade climática, vulnerabilidade social e saúde no Brasil. Terra Livre. 2003;1(20):193-204, .

26. Secretaria Estadual de Saúde. Plano Integrado de Ações para o Enfrentamento às Doenças Negligenciadas. Programa SANAR. $2^{a}$ Edição. 2015-2018. Pernambuco: Secretaria de Saúde do Estado de Pernambuco, 2015. Citado: 23 ago 2017. Disponível em: http:// portal.saude.pe.gov.br/sites/portal.saude.pe.gov.br/files/plano sanar_2_edicao_29.08.17.pdf

27. Harvay MO, Olliaro PL, Costa DL, Costa CH. Urban parasitology: visceral leishmaniasis in Brazil. Trends Parasitol. 2011;27(9):403-9.

28. Prado PF, Rocha MF, Sousa JF, Caldeira DI, Paz GF, Dias ES. Epidemiological aspects of human and canine visceral Leishmaniasis in Montes Claros, State of Minas Gerais, Brazil, between 2007 and 2009. Rev Soc Bras Med Trop. 2011;44(5):561-6.

29. Moreno EC, Melo MN, Antunes CMF, Lambertucci JR, Serufo JC, Andrade ASR, et al. Epidemiologia da leishmaniose visceral humana assintomática em área urbana, Sabará, Minas Gerais, 19981999. Inf Epidemiol Sus. 2002;11(1):37-9.

30. Stockdale L, Newton R. A review of preventative methods against human leishmaniasis infection. PLoS Negl Trop Dis. 2013;7(6):e2278.

31. Correia LOS, Padilha BM, Vasconcelos SML. Methods for assessing the completeness of data in health information systems in Brazil: a systematic review. Cien Saude Colet. 2014;19(11):4467-78.

32. Costa JMBS, Frias PG. Avaliação da completitude das variáveis da Declaração de Nascido Vivo de residentes em Pernambuco, Brasil, 1996 a 2005. Cad Saude Publica. 2009;25(3):613-24.

33. Cruz MM, Toledo LM, Santos EM. O sistema de informação de AIDS do município do Rio de Janeiro: suas limitações e potencialidades enquanto instrumento da vigilância epidemiológica. Cad Saude Publica. 2003;19(1):81-9.

34. Romero DE, Cunha CB. Avaliação da qualidade das variáveis epidemiológicas e demográficas do Sistema de Informações sobre Nascidos Vivos, 2002. Cad Saude Publica. 2007;23(3):701-14.

35. Programa das Nações Unidas para o Desenvolvimento (PNDU). Desenvolvimento humano e IDH - o que é o IDH. 2017. Citado: 3 out 2017. Disponível em: http://www.pnud.org.br/IDH/ IDH. aspx?indiceAccordion $=0 \& 1 \mathrm{l}=\mathrm{li}$ IDH. 
36. Oliveira LS, Dias Neto RV, Braga PET. Perfil epidemiológico dos casos de leishmaniose visceral em Sobral, Ceará, no período de 2001 a 2010. SANARE: Sobral. 2013;12(1):13-19.

37. Barreto JHS. Diferenças raciais e a sua relação com a saúde. Rev Baiana Saude Publ. 2004;28(2):242-58.

38. Pan American Health Organization/World Health Organization (PAHO-WHO). Leishmaniases. Epidemiological Report of the Americas. Report Leishmaniasis $\mathrm{n}^{\circ}$ 2. 2014. Citado 31 jul 2017. Disponível em: <http://www.paho.org/hq/index.php?option=com docman\&task=doc_view\&gid=27080\&Itemid

39. Batista FMA, Machado FFOA, Silva JMO, Mittmann J, Barja PR, Simioni AR. Leishmaniose: perfil epidemiológico dos casos notificados no estado do Piauí entre 2007 e 2011. Rev UNIVAP. 2014;20(35).

40. Oliveira EN, Pimenta AM. Perfil epidemiológico das pessoas portadoras de leishmaniose visceral no município de Paracatu-MG no período de 2007 a 2010. REME. 2014;18(2):365-70.

41. Cavalcante, IJM, Vale MR. Aspectos epidemiológicos da leishmaniose visceral (calazar) no Ceará no período de 2007 a 2011. Rev Bras Epidemiol. 2014;17(4): 911-24.
42. Viana GMC, Neto da Silva MAC, Pinheiro FCM, Branco RCC, Bezerra GFB, Nascimento MDSB. Série temporal de casos de leishmaniose visceral em São Luís, Maranhão, Brasil (2001 a 2013): aspectos epidemiológicos e clínicos. Rev Invest Bioméd. 2015;7(1):80-90.

43. Góes MAO, Melo CM, Jeraldo VLS. Time series of visceral leishmaniasis in Aracaju, state of Sergipe, Brazil (1999 to 2008): human and canine aspects. Rev Bras Epidemiol. 2012;15(2):298-307.

44. Sousa-Gomes ML, Maia-Elkhoury ANS, Pelissari DM, Lima Junior FEF, Sena JM, Cechinel MP. Coinfecção Leishmania no Brasil: aspectos epidemiológicos, clínicos e laboratoriais. Epidemiol Serv Saude. 2011;20(4):519-26.

45. Maia-Elkhoury ANS, Alves WA, Sousa-Gomes ML, Sena JM, Luna EA. Visceral leishmaniasis in Brazil: trends and challenges. Cad Saude Publica. 2008;24(12): 2941-47.

46. Lindoso JAL, Cruz LL, Spinola RMF, Fortaleza CMCB, Nogueira PA, Madalosso G. Fatores associados à leishmaniose visceral grave. Rev Soc Bras Med Trop. 2006;39(S III):133-4.

47. Alvarenga DG, Escalda PMF, Costa ASV, Monreal MTFD. Leishmaniose visceral: estudo retrospectivo de fatores associados à letalidade. Rev Soc Bras Med Trop. 2010;43(2):194-97. 